\title{
Biochemical responses of cucumber to Tetranychus urticae Koch (Acari: Tetranychidae) mediated biotic stress
}

\author{
Kanika Tehri*, Rachna Gulati, Monika Geroh and Shashi Madan \\ Department of Zoology, CCS Haryana Agricultural University, Hisar- 125 004, INDIA \\ ${ }^{1}$ Department of Biochemistry, CCS Haryana Agricultural University, Hisar- 125 004, INDIA \\ *Corresponding author. E- mail: knkzoology@gmail.com
}

Received: July 15, 2014; Revised received: September 26, 2014; Accepted: November 21, 2014

\begin{abstract}
The effect of two spotted spider mite (Tetranychus urticae Koch) feeding on leaf level physiological characteristics of cucumber (Cucumis sativus Linnaeus) was investigated. Young cucumber plants were artificially infested with different densities of $T$. urticae $(5,10,15$ and 20 mites/ grown up leaf) while uninfested plants acted as control. Post infestation, the plants differed in their support to mite density in accordance with initial infestation density and observation period. Highly significant negative correlation of $-0.92,-0.93,-0.95$ and -0.92 for total chlorophyll, chlorophyll a, chlorophyll b and carotenoids, respectively, at the highest infestation level) was recorded between mite density and photosynthetic pigments in infested leaves as compared to uninfested ones. There was a significant decrease $(P=0.05)$ in the level of (a progressive decline from $2.82,0.36$ and $2.17 \%$ dry weight in control to the maximum of $2.09,0.26$ and $1.87 \%$ dry weight for $\mathrm{N}, \mathrm{P}$ and $\mathrm{K}$, respectively, at highest infestation level) in the infested leaves in response to mite infestation. Interaction between initial infestation level and observation period also suggested a significant impact of $T$. urticae infestation on the leaf phytochemicals of cucumber $(P=0.05)$.
\end{abstract}

Keywords: Cucumis sativus, Feeding, Infestation density, Phytochemicals, Tetranychus urticae

\section{INTRODUCTION}

The two-spotted spider mite, Tetranychus urticae Koch (Acari: Tetranychidae), is amongst the most damaging agricultural pests worldwide belonging to an assemblage of web-spinning mites. T. urticae represents one of the most polyphagous arthropod herbivores, feeding on more than 1,100 plant species belonging to more than 140 different plant families including species known to produce toxic compounds (Van Leeuwen et al., 2010). It is the most notorious pest responsible for significant yield losses in many economic crops, vegetables and fruit trees (Salman, 2007) and also ornamental and agronomic crops worldwide (James and Price, 2002). The rapid developmental rate, high reproductive potential, and arrhenotokous parthenogenesis in T. urticae allows them to achieve damaging population levels very quickly when growth conditions are good, resulting in an equally rapid decline of host plant quality. This mite is particularly dominant in intensive, high yield cropping systems and affects crops by direct feeding; thereby reducing the area of photosynthetic activity and causing leaf abscission in severe infestations (Gorman et al., 2001). Puncturing of cells by mite stylets and injection of saliva causes mechanical damage, changes in cell cytology, physiological and biochemical processes of punctured as well as non-punctured adjacent cells (Tomczyk and Kropczynska, 1985).
Heavy damage may cause leaves to dry and drop and the plants may be covered with webbing (Abdel-Wali et al., 2012). The webbings produced by protonymphs, deutonymphs and adults and hampering of photosynthetic activity may result in a reduction in crop yield as well as aesthetic injuries (Dutta et al., 2012). When the plant begins to decline, resulting in a reduced food supply, the mites enter a dispersal phase from sedentary phase and aggregate on the uppermost parts of the plants. Dispersal includes both intraplant and interplant movement. Aerial dispersal begins with the mites aggregating on the uppermost portions of the plants. The mites produce threads of silk, which they use to "balloon" into the wind, which sometimes carry them great distances (Kennedy and Smitley, 1985). T. urticae infestation represents potential biotic stress to its host plant and adversely affects many physiological and biochemical processes (Sivritepe et al., 2009). Computer modelling suggests that with intensifying global warming, the detrimental effects of spider mites in agriculture will markedly increase due to accelerated development at higher temperatures. A thorough understanding of pest ecology and host plant physiology is necessary to understand host-plant relationships and host resistance mechanisms. This is especially important for elaborating integrated pest management strategies in agriculture and reducing yield loss. There is only scarce information on the impact of two spotted spider mites 
on cucumber physiology (Park and Lee, 2002). The objective of the present study was to investigate the effect of $T$. urticae infestation on leaf-level physiological characteristics of cucumbers.

\section{MATERIALS AND METHODS}

Mite culture: The base population was originally collected from okra plants from University Research Farm Area and since then maintained on potted okra (var.Varsha uphar) and cucumber (var. Damini hybrid) plants in the screenhouse of Department of Zoology, Chaudhary Charan Singh Haryana Agricultural University, Hisar.

Raising of crop and $T$. urticae inoculation: The field experiment was conducted in the Research Farm Area, Department of Entomology, CCSHAU, Hisar during 2012. Cucumber (Cucumis sativus L.) var. Damini hybrid seeds were sown in early April, 2012 and the crop was raised following standard agronomical practices. No insecticide, miticide or any other chemicals were applied to control the pest. The plants were divided into five treatment groups within a complete randomized block design consisting of ten replicates per treatment. The adult females of $T$. urticae, from stock culture in screenhouse, were artificially inoculated on 20 days old plants by placing them onto the fully expanded grown up leaves with the help of bird feather pick. Inoculation was done as 5, 10, 15 and 20 mites released per grown up leaf under different treatments $\left(T_{2}, T_{3}, T_{4}\right.$ and $T_{5}$, respectively). Uninfested plants served as control $\left(\mathrm{T}_{1}\right)$.

Phytochemical screening: Mite population was allowed to increase naturally. Each treatment group was further subdivided into three sets of different durations viz., 20, 40 and 60 days. Estimation of respective phytochemicals on 0 day acted as corresponding control. Leaf samples were collected per plant and the number of T. urticae per sq. cm leaf counted. Visual symptoms of chlorosis appeared on the leaves. Collected leaves were then weighed on electronic balance, washed with distilled water in order to avoid contamination and air dried for 15 minutes. The samples were then allowed to dry in an oven at $60^{\circ} \mathrm{C}$ till they attained a constant dry weight and ground in a Micro-Willey grinding mill (0.2 mm sieve) for analysis of various phytochemicals (nitrogen, potassium, phosphorus) except photosynthetic pigments for which fresh leaf samples were used. The photosynthetic pigments were estimated as per the method of Hiscox and Israelstam (1979). To estimate minerals, digestion of sample was carried out. Powdered material (100 mg) was taken in $100 \mathrm{ml}$ conical flask and $10 \mathrm{ml}$ diacid mixture (Sulphuric acid + Perchloric acid; 4:1) was added to each flask (Fiske and Subba Row, 1925). These flasks were covered with watch glass and allowed to stand overnight. Heating was done until solid particles had nearly disappeared and clear colourless solution was obtained. Then one $\mathrm{ml}$ of $\mathrm{HCl}$ concentrate was added to each sample and again heated until colourless solution was obtained. Solutions were allowed to cool and the volume was made to $25 \mathrm{ml}$ with 1 per cent $\mathrm{HCl}$ in distilled water. Blank was also run simultaneously but without sample. These solutions were mixed thoroughly and used for analysis mineral estimation. Leaf-nitrogen content was estimated using the method of Lindner (1944). Phosphorus was estimated by the method of Jackson (1973). Potassium in the digested sample was estimated in the above acid digest with a Micro Flame Photometer (Elico CL 361, India) by direct reading (Richards, 1954).

Statistical analysis: The statistical significance of data was assessed through two factorial analysis of variance (ANOVA) using OPSTAT software and means were then compared using Duncan's multiple range test $(\mathrm{P}=0.05)$. Correlation coefficient ' $\mathrm{r}$ ' was calculated to see the effect of mite incidence on various parameters evaluated.

\section{RESULTS AND DISCUSSION}

The number of two spotted spider mite mobile forms elevated in the inoculated plants during the 60 days experimental period. Heavy patching on tender, grown up and older leaves of cucumber coincided with initial inoculum of $T$. urticae. Data pertaining to changes in the photosynthetic pigments (total chlorophyll, chlorophyll a, chlorophyll b, carotenoids) due to mite infestation on cucumber leaves are presented in Tables 1-4. Results showed a significant progressive decline in all the photosynthetic pigments with increase in duration and density of mite infestation $(\mathrm{P}=0.05)$. Total chlorophyll content was found to be at par for the treatments $\mathrm{T}_{2}$ and $\mathrm{T}_{3} ; \mathrm{T}_{4}$ and $\mathrm{T}_{5}$, respectively (Table 1; $\mathrm{P}=0.05)$. The chlorophyll a content in $\mathrm{T}_{3}$ showed no significant difference with the treatments $\mathrm{T}_{4}$ and $\mathrm{T}_{5}$ (Table 2; $\mathrm{P}=0.05$ ). Likewise, the chlorophyll $\mathrm{b}$ content in $\mathrm{T}_{2}$ and $\mathrm{T}_{3} ; \mathrm{T}_{4}$ and $\mathrm{T}_{5}$ was found to show statistically insignificant difference between respective treatments (Table 3; $\mathrm{P}=0.05$ ). The chlorophyll c content in $\mathrm{T}_{4}$ was found to be at par with chlorophyll c content recorded for $\mathrm{T}_{3}$ and $\mathrm{T}_{5}$ (Table $\left.4 ; \mathrm{P}=0.05\right)$. Reduction in chlorophyll content is a primary response to spider mite infestation as it feeds on photosyntetically active cells. When the two spotted spider mites start to feed on the under surface of leaves, the mesophyll tissue collapses and a small chlorotic patch is formed at each feeding site. The amount and rate of change of the chlorophyll has been reported to depend on T. urticae density and duration of feeding (Alatawi et al., 2007) and is supported in the current work. Decrease in chlorophyll-a was more pronounced than chlorophyll-b at different stages of $T$. urticae infestation as per the findings of Farouk and Osman (2011). The major principles behind yield losses due to spider mite infestation in various crops have been established as biomass reduction, disturbance of water conduction, dry matter partitioning, $\mathrm{CO}_{2}$ gas exchange, chlorophyll 
Table 1. Effect of initial infestation density of T. urticae on the total chlorophyll content ( $\mathrm{mg} / \mathrm{g}$ fresh weight) of cucumber leaves.

\begin{tabular}{|c|c|c|c|c|c|c|c|c|c|}
\hline \multirow{3}{*}{ Treatment } & \multicolumn{8}{|c|}{ Days of infestation } & \multirow{3}{*}{ Mean } \\
\hline & \multicolumn{2}{|r|}{$\mathbf{0}$} & \multicolumn{2}{|r|}{20} & \multicolumn{2}{|c|}{40} & \multicolumn{2}{|r|}{60} & \\
\hline & $\begin{array}{l}\text { Mite } \\
\text { no. }\end{array}$ & $\begin{array}{c}\text { Total } \\
\text { chlorophyll }\end{array}$ & $\begin{array}{l}\text { Mite } \\
\text { no. }\end{array}$ & $\begin{array}{c}\text { Total } \\
\text { chlorophyll }\end{array}$ & $\begin{array}{l}\text { Mite } \\
\text { no. }\end{array}$ & $\begin{array}{c}\text { Total } \\
\text { chlorophyll }\end{array}$ & $\begin{array}{l}\text { Mite } \\
\text { no. }\end{array}$ & $\begin{array}{c}\text { Total } \\
\text { chlorophyll }\end{array}$ & \\
\hline $\begin{array}{l}\mathrm{T}_{1} \text { (No release- } \\
\text { control) }\end{array}$ & 0.00 & 2.58 & 0.00 & 2.57 & 0.00 & 2.57 & 0.00 & 2.57 & 2.57 \\
\hline $\begin{array}{l}\mathrm{T}_{2} \\
(5 \text { mites released })\end{array}$ & 0.00 & 2.57 & 3.43 & 1.17 & 11.97 & 1.15 & 13.13 & 0.93 & $1.45^{\mathrm{a}}$ \\
\hline $\begin{array}{l}T_{3} \\
\text { (10 mites released) }\end{array}$ & 0.00 & 2.56 & 3.98 & 1.15 & 14.98 & 1.12 & 16.48 & 0.88 & $1.43^{\mathrm{a}}$ \\
\hline $\begin{array}{l}T_{4} \\
\text { (15 mites released) }\end{array}$ & 0.00 & 2.58 & 4.95 & 1.13 & 16.92 & 1.01 & 19.79 & 0.86 & $1.39^{\mathrm{b}}$ \\
\hline $\begin{array}{l}T_{5} \\
(20 \text { mites released })\end{array}$ & 0.00 & 2.56 & 8.13 & 1.13 & 21.48 & 0.98 & 23.36 & 0.80 & $1.37^{\mathrm{b}}$ \\
\hline Mean & & 2.57 & & 1.43 & & 1.36 & & 1.21 & \\
\hline $\begin{array}{l}\text { Correlation with } \\
\text { mite population }\end{array}$ & & & & 0.79 & & 0.94 & & -0.92 & \\
\hline
\end{tabular}

Mite no. expressed as no. of mites/sq. cm leaf; $C D(P=0.05)$ for Treatment $(T)=0.06$; Duration $(D)=0.06 ; T \times D=0.15 ;$ Values with the same superscript do not differ significantly

Table 2. Effect of initial infestation density of $T$. urticae on the chlorophyll a content ( $\mathrm{mg} / \mathrm{g}$ fresh weight) of cucumber leaves.

\begin{tabular}{|c|c|c|c|c|c|c|c|c|c|}
\hline \multirow{3}{*}{ Treatment } & \multicolumn{8}{|c|}{ Days of infestation } & \multirow[b]{3}{*}{ Mean } \\
\hline & \multicolumn{2}{|r|}{$\mathbf{0}$} & \multicolumn{2}{|r|}{20} & \multicolumn{2}{|c|}{40} & \multicolumn{2}{|r|}{60} & \\
\hline & $\begin{array}{c}\text { Mite } \\
\text { no. }\end{array}$ & $\begin{array}{c}\text { Chlorophyll } \\
\text { a } \\
\end{array}$ & $\begin{array}{l}\text { Mite } \\
\text { no. }\end{array}$ & $\begin{array}{c}\text { Chlorophyll } \\
\text { a } \\
\end{array}$ & $\begin{array}{c}\text { Mite } \\
\text { no. }\end{array}$ & $\begin{array}{c}\text { Chlorphyll } \\
\text { a } \\
\end{array}$ & $\begin{array}{c}\text { Mite } \\
\text { no. }\end{array}$ & $\begin{array}{c}\text { Chlorophyll } \\
\text { a } \\
\end{array}$ & \\
\hline $\begin{array}{l}\mathrm{T}_{1} \text { (No release - } \\
\text { control) }\end{array}$ & 0.00 & 2.02 & 0.00 & 2.02 & 0.00 & 2.01 & 0.00 & 2.02 & 2.02 \\
\hline $\begin{array}{l}\mathrm{T}_{2} \\
\text { (5 mites released) }\end{array}$ & 0.00 & 2.02 & 3.43 & 0.93 & 11.97 & 0.89 & 13.13 & 0.70 & $1.13^{\mathrm{a}}$ \\
\hline $\begin{array}{l}T_{3} \\
\text { (10 mites released) }\end{array}$ & 0.00 & 2.01 & 3.98 & 0.86 & 14.98 & 0.85 & 16.48 & 0.65 & $1.09^{\mathrm{a}, \mathrm{b}}$ \\
\hline $\begin{array}{l}\mathrm{T}_{4} \\
(15 \text { mites released })\end{array}$ & 0.00 & 2.03 & 4.95 & 0.84 & 16.92 & 0.76 & 19.79 & 0.64 & $1.06^{\mathrm{b}}$ \\
\hline $\begin{array}{l}\mathrm{T}_{5} \\
\text { (20 mites released) }\end{array}$ & 0.00 & 2.02 & 8.13 & 0.84 & 21.48 & 0.73 & 23.36 & 0.61 & 1.04 \\
\hline Mean & & 2.02 & & 1.10 & & 1.05 & & 0.92 & \\
\hline $\begin{array}{l}\text { Correlation } \\
\text { with mite } \\
\text { population }\end{array}$ & & & & 0.81 & & 0.95 & & -0.93 & \\
\hline
\end{tabular}

Mite no. expressed as no. of mites/sq. cm leaf; $C D(P=0.05)$ for Treatment $(T)=0.06$; Duration $(D)=0.06 ; T \times D=0.15$; Values with the same superscript do not differ significantly

reduction and shedding of immature flowers (Park and Lee, 2002). T. urticae feeding causes the destruction of chloroplasts by puncturing photosynthetically active cells (Sivritepe et al., 2009) which then leads to basic physiological changes in the plant. In gut content studies of two-spotted mites, Walsh (2001) observed the presence of only thylakoid granules, the key photosynthetic engines in plant cells, following feeding.

Data pertaining to changes in mineral content (Nitrogen, Phosphorus and Potassium) of cucumber leaves as a result of $T$. urticae feeding at different initial infestation levels are presented in Tables 5-7. Significant negative correlation between mite number and nitrogen content clearly depicted decrease in nitrogen content with increase in mite number at different durations of treatment $(\mathrm{r}=-0.98,-0.98$ and 0.99 at 20, 40 and 60 days). Significant difference was recorded for nitrogen content of cucumber leaves in all the treatments (Table $6 ; \mathrm{P}=0.05$ ). Similar results were obtained for phosphorus (Table 6) and potassium (Table 7) content in cucumber leaves, showing a significant decrease with increase in initial infestation density of $T$. urticae as well as duration of infestation. For the treatment $T_{3}$, the Phosphorus content was found to exhibit insignificant difference with the treatments $\mathrm{T}_{2}$ and $\mathrm{T}_{3}$ (Table $7 ; \mathrm{P}=0.05$ ). However, Potassium content was found to be at par for the treatments $\mathrm{T}_{2}$ and $\mathrm{T}_{3}$ (Table 7; $\mathrm{P}=0.05$ ). Sivritepe et al. (2009) reported a fall in Calcium, Potassium and Magnesium contents of sultana cultivar of grapevine in response to T. urticae infestation. Farouk and Osman (2011) have recently suggested that infestation with $T$. urticae results in increased production of reactive oxygen species (ROS) which destroys membrane permeability thus leading to decreased content of minerals 
Table 3. Effect of initial infestation density of T. urticae on the chlorophyll b content ( $\mathrm{mg} / \mathrm{g}$ fresh weight) of cucumber leaves.

\begin{tabular}{|c|c|c|c|c|c|c|c|c|c|}
\hline \multirow{3}{*}{ Treatment } & \multicolumn{8}{|c|}{ Days of infestation } & \multirow{3}{*}{ Mean } \\
\hline & \multicolumn{2}{|r|}{$\mathbf{0}$} & \multicolumn{2}{|r|}{20} & \multicolumn{2}{|r|}{40} & \multicolumn{2}{|r|}{60} & \\
\hline & $\begin{array}{l}\text { Mite } \\
\text { no. }\end{array}$ & $\begin{array}{c}\text { Chlorophyll } \\
\text { b }\end{array}$ & $\begin{array}{c}\text { Mite } \\
\text { no. }\end{array}$ & $\begin{array}{c}\text { Chlorophyll } \\
\text { b }\end{array}$ & $\begin{array}{c}\text { Mite } \\
\text { no. }\end{array}$ & $\begin{array}{c}\text { Chlorophyll } \\
\text { b }\end{array}$ & $\begin{array}{c}\text { Mite } \\
\text { no. }\end{array}$ & $\begin{array}{c}\text { Chlorophyll } \\
\text { b }\end{array}$ & \\
\hline $\begin{array}{l}\mathrm{T}_{1} \text { (No release } \\
\text { control) }\end{array}$ & 0.00 & 0.56 & 0.00 & 0.56 & 0.00 & 0.56 & 0.00 & 0.56 & 0.56 \\
\hline $\begin{array}{l}\mathrm{T}_{2}(5 \text { mites } \\
\text { released })\end{array}$ & 0.00 & 0.55 & 3.43 & 0.32 & 11.97 & 0.29 & 13.13 & 0.24 & $0.35^{\mathrm{a}}$ \\
\hline $\begin{array}{l}\mathrm{T}_{3}(10 \text { mites } \\
\text { released })\end{array}$ & 0.00 & 0.57 & 3.98 & 0.28 & 14.98 & 0.27 & 16.48 & 0.23 & $0.34^{\mathrm{a}}$ \\
\hline $\begin{array}{l}\mathrm{T}_{4}(15 \text { mites } \\
\text { released })\end{array}$ & 0.00 & 0.56 & 4.95 & 0.28 & 16.92 & 0.25 & 19.79 & 0.21 & $0.33^{\mathrm{b}}$ \\
\hline $\begin{array}{l}\mathrm{T}_{5}(20 \text { mites } \\
\text { released) }\end{array}$ & 0.00 & 0.56 & 8.13 & 0.28 & 21.48 & 0.25 & 23.36 & 0.19 & $0.32^{\mathrm{b}}$ \\
\hline Mean & & 0.56 & & 0.35 & & 0.32 & & 0.29 & \\
\hline $\begin{array}{l}\text { Correlation } \\
\text { with mite } \\
\text { population }\end{array}$ & & & & 0.82 & & 0.94 & & 0.95 & \\
\hline
\end{tabular}

Mite no. expressed as no. of mites/sq. cm leaf; $C D(P=0.05)$ for Treatment $(T)=0.06$; Duration $(D)=0.06 ; T \times D=0.15$; Values with the same superscript do not differ significantly

Table 4. Effect of initial infestation density of T. urticae on the carotenoid content (mg/ $\mathrm{g}$ fresh weight) of cucumber leaves.

\begin{tabular}{|c|c|c|c|c|c|c|c|c|c|}
\hline \multirow{3}{*}{ Treatment } & \multicolumn{8}{|c|}{ Days of infestation } & \multirow{3}{*}{ Mean } \\
\hline & \multicolumn{2}{|r|}{$\overline{\mathbf{0}}$} & \multicolumn{2}{|r|}{20} & \multicolumn{2}{|r|}{40} & \multicolumn{2}{|r|}{60} & \\
\hline & $\begin{array}{c}\text { Mite } \\
\text { no. }\end{array}$ & Carotenoid & $\begin{array}{c}\text { Mite } \\
\text { no. }\end{array}$ & Carotenoid & $\begin{array}{c}\text { Mite } \\
\text { no. }\end{array}$ & Carotenoid & $\begin{array}{c}\text { Mite } \\
\text { no. }\end{array}$ & Carotenoid & \\
\hline $\begin{array}{l}\mathrm{T}_{1} \text { (No release } \\
\text { control) }\end{array}$ & 0.00 & 0.56 & 0.00 & 0.54 & 0.00 & 0.55 & 0.00 & 0.55 & 0.55 \\
\hline $\begin{array}{l}T_{2}(5 \text { mites } \\
\text { released })\end{array}$ & 0.00 & 0.56 & 3.43 & 0.29 & 11.97 & 0.26 & 13.13 & 0.19 & 0.33 \\
\hline $\begin{array}{l}\mathrm{T}_{3}(10 \text { mites } \\
\text { released })\end{array}$ & 0.00 & 0.55 & 3.98 & 0.26 & 14.98 & 0.23 & 16.48 & 0.18 & $0.31^{\mathrm{a}}$ \\
\hline $\begin{array}{l}\mathrm{T}_{4}(15 \text { mites } \\
\text { released })\end{array}$ & 0.00 & 0.55 & 4.95 & 0.26 & 16.92 & 0.22 & 19.79 & 0.17 & $0.30^{\mathrm{a}, \mathrm{b}}$ \\
\hline $\begin{array}{l}\mathrm{T}_{5}(20 \text { mites } \\
\text { released })\end{array}$ & 0.00 & 0.56 & 8.13 & 0.25 & 21.48 & 0.21 & 23.36 & 0.17 & $0.29^{\mathrm{b}}$ \\
\hline Mean & & 0.55 & & 0.32 & & 0.29 & & 0.25 & \\
\hline $\begin{array}{l}\text { Correlation } \\
\text { with mite } \\
\text { population }\end{array}$ & & & & 0.83 & & -0.94 & & -0.92 & \\
\hline
\end{tabular}

Mite no. expressed as no. of mites/sq. cm leaf; $C D(P=0.05)$ for Treatment $(T)=0.06$; Duration $(D)=0.06 ; T \times D=0.15$; Values with the same superscript do not differ significantly

due to its effect on ion uptake. This reduction may also be due to less drain of phloem sap by $T$. urticae population. However, accumulation of some minerals (Sodium, Copper and Zinc) and inorganic ions has also been reported in muskule cultivar of grapevine which may contribute to osmotic adjustment in the leaves experiencing T. urticae induced water stress (Sivritepe et al., 2009). To date, the data on the relationship between mite feeding and changes in the mineral composition of leaf tissue are scarce and more studies are needed to shed light on this arena.

\section{Conclusion}

Highly significant negative correlation was recorded between mite density and various phytochemicals (photosynthetic pigments and mineral content) in infested leaves as compared to uninfested ones. Interaction between initial infestation level and observation period suggested a significant impact of T. urticae infestation on the leaf phytochemicals of cucumber. The findings indicated that substantial physiological impact on cucumber is possible even at low T. urticae densities and timely management of the pest is suggested to allow potential higher benefit to the growers.

\section{REFERENCES}

Abdel-Wali, M., Mustafa, T. and Al-Lala, M. (2012). Residual toxicity of abametin, milbemectin and chlorfenapyr to different populations of two-spotted spider mite, Tetranychus urticae Koch, (Acari: Tetranychidae) on 
Table 5. Effect of initial infestation density of T. urticae on the Nitrogen content (\% dry weight) of cucumber leaves.

\begin{tabular}{|c|c|c|c|c|c|c|c|c|c|}
\hline \multirow{3}{*}{ Treatment } & \multicolumn{8}{|c|}{ Days of infestation } & \multirow{3}{*}{ Mean } \\
\hline & \multicolumn{2}{|c|}{$\mathbf{0}$} & \multicolumn{2}{|c|}{20} & \multicolumn{2}{|c|}{40} & \multicolumn{2}{|c|}{60} & \\
\hline & Mite no. & $\mathbf{N}$ & Mite no. & $\mathbf{N}$ & Mite no. & $\mathbf{N}$ & Mite no. & $\mathbf{N}$ & \\
\hline $\begin{array}{l}\mathrm{T}_{1}(\text { No release } \\
\text { control) }\end{array}$ & 0.00 & 2.84 & 0.00 & 2.83 & 0.00 & 2.82 & 0.00 & 2.82 & 2.83 \\
\hline $\begin{array}{l}\mathrm{T}_{2}(5 \text { mites } \\
\text { released })\end{array}$ & 0.00 & 2.84 & 3.43 & 2.71 & 11.97 & 2.44 & 13.13 & 2.39 & 2.59 \\
\hline $\begin{array}{l}\mathrm{T}_{3}(10 \text { mites } \\
\text { released })\end{array}$ & 0.00 & 2.84 & 3.98 & 2.68 & 14.98 & 2.37 & 16.48 & 2.28 & 2.54 \\
\hline $\begin{array}{l}\mathrm{T}_{4}(15 \text { mites } \\
\text { released })\end{array}$ & 0.00 & 2.84 & 4.95 & 2.65 & 16.92 & 2.29 & 19.79 & 2.19 & 2.49 \\
\hline $\begin{array}{l}\mathrm{T}_{5}(20 \text { mites } \\
\text { released })\end{array}$ & 0.00 & 2.85 & 8.13 & 2.58 & 21.48 & 2.22 & 23.36 & 2.09 & 2.43 \\
\hline Mean & & 2.84 & & 2.69 & & 2.42 & & 2.35 & \\
\hline $\begin{array}{l}\text { Correlation } \\
\text { with mite } \\
\text { population }\end{array}$ & & & & -0.98 & & -0.98 & & -0.99 & \\
\hline
\end{tabular}

Mite no. expressed as no. of mites/sq. cm leaf; $\mathrm{CD}(\mathrm{P}=0.05)$ for Treatment $(\mathrm{T})=0.06$; Duration $(\mathrm{D})=0.06 ; \mathrm{T} \times \mathrm{D}=0.15$

Table 6. Effect of initial infestation density of T. urticae on the Phosphorus content (\% dry weight) of cucumber leaves.

\begin{tabular}{|c|c|c|c|c|c|c|c|c|c|}
\hline \multirow{3}{*}{ Treatment } & \multicolumn{8}{|c|}{ Days of infestation } & \multirow{3}{*}{ Mean } \\
\hline & \multicolumn{2}{|c|}{$\mathbf{0}$} & \multicolumn{2}{|c|}{20} & \multicolumn{2}{|c|}{40} & \multicolumn{2}{|c|}{60} & \\
\hline & Mite no. & $\mathbf{P}$ & Mite no. & $\mathbf{P}$ & Mite no. & $\mathbf{P}$ & Mite no. & $\mathbf{P}$ & \\
\hline $\mathrm{T}_{1}$ (No release -control) & 0.00 & 0.36 & 0.00 & 0.36 & 0.00 & 0.36 & 0.00 & 0.36 & 0.36 \\
\hline $\mathrm{T}_{2}(5$ mites released $)$ & 0.00 & 0.36 & 3.43 & 0.35 & 11.97 & 0.33 & 13.13 & 0.31 & $0.34^{\mathrm{a}}$ \\
\hline $\mathrm{T}_{3}(10$ mites released $)$ & 0.00 & 0.36 & 3.98 & 0.34 & 14.98 & 0.32 & 16.48 & 0.29 & $0.33^{\mathrm{a}, \mathrm{b}}$ \\
\hline $\mathrm{T}_{4}(15$ mites released $)$ & 0.00 & 0.36 & 4.95 & 0.33 & 16.92 & 0.31 & 19.79 & 0.27 & $0.32^{\mathrm{b}}$ \\
\hline $\mathrm{T}_{5}(20$ mites released $)$ & 0.00 & 0.36 & 8.13 & 0.31 & 21.48 & 0.29 & 23.36 & 0.26 & 0.30 \\
\hline Mean & & 0.36 & & 0.34 & & 0.32 & & 0.30 & \\
\hline $\begin{array}{l}\text { Correlation } \\
\text { with mite population }\end{array}$ & & & & -0.96 & & -0.98 & & -0.99 & \\
\hline
\end{tabular}

Mite no. expressed as no. of mites/sq. cm leaf; $C D(P=0.05)$ for Treatment $(T)=0.06$; Duration $(D)=0.06 ; T \times D=0.15$; Values with the same superscript do not differ significantly

Table 7. Effect of initial infestation density of T. urticae on the Potassium content (\% dry weight) of cucumber leaves.

\begin{tabular}{|c|c|c|c|c|c|c|c|c|c|}
\hline \multirow{3}{*}{ Treatment } & \multicolumn{8}{|c|}{ Days of infestation } & \multirow{3}{*}{ Mean } \\
\hline & \multicolumn{2}{|c|}{$\mathbf{0}$} & \multicolumn{2}{|c|}{20} & \multicolumn{2}{|c|}{40} & \multicolumn{2}{|c|}{60} & \\
\hline & Mite no. & $\mathbf{K}$ & Mite no. & $\mathbf{K}$ & Mite no. & $\mathbf{K}$ & Mite no. & $\mathbf{K}$ & \\
\hline $\mathrm{T}_{1}$ (No release -control) & 0.00 & 2.17 & 0.00 & 2.17 & 0.00 & 2.17 & 0.00 & 2.17 & 2.17 \\
\hline $\mathrm{T}_{2}(5$ mites released $)$ & 0.00 & 2.17 & 3.43 & 2.08 & 11.97 & 2.03 & 13.13 & 1.96 & $2.05^{\mathrm{a}}$ \\
\hline $\mathrm{T}_{3}(10$ mites released $)$ & 0.00 & 2.18 & 3.98 & 2.06 & 14.98 & 1.99 & 16.48 & 1.92 & $2.04^{\mathrm{a}}$ \\
\hline $\mathrm{T}_{4}(15$ mites released $)$ & 0.00 & 2.18 & 4.95 & 2.05 & 16.92 & 1.97 & 19.79 & 1.89 & 2.02 \\
\hline $\mathrm{T}_{5}(20$ mites released $)$ & 0.00 & 2.17 & 8.13 & 2.03 & 21.48 & 1.93 & 23.36 & 1.87 & 2.00 \\
\hline Mean & & 2.17 & & 2.08 & & 2.02 & & 1.96 & \\
\hline $\begin{array}{l}\text { Correlation } \\
\text { with mite population }\end{array}$ & & & & -0.93 & & -0.99 & & -0.96 & \\
\hline
\end{tabular}

Mite no. expressed as no. of mites/sq. cm leaf; $C D(P=0.05)$ for Treatment $(T)=0.06$; Duration $(D)=0.06 ; T \times D=0.15$; Values with the same superscript do not differ significantly

cucumber in Jordan. World J. Agric. Sci. 8(2): 174-178.

Alatawi, F.J., Margolies, D.C. and Nechols, J.R. (2007). Aesthetic damage thresholds for two spotted spider mites (Acari: Tetranychidae) on impatiens: effect of plant age and level of infestation. J. Econ. Entomol. 100: 1904-1909.

Dutta, N.K., Alam, S.N., Uddin, M.K., Mahmudunnabi, M. and Khatun, M.F. (2012). Population abundance of red spider mite in different vegetables along with its spatial distribution and chemical control in brinjal, Solanum melongena L. Bangladesh J Agril Res. 37(3): 399-404.

Farouk, S. and Osman, M.A. (2011). The effect of plant defence elicitors on common bean (Phaseolus vulgaris L.) growth and yield in absence or presence of spider mite (Tetranychus urticae Koch) infestation. J. Stress Physiol. and Biochem. 7(3): 6-22.

Fiske, C.H. and SubbaRow, Y. (1925). The colorimetric determination of phosphorus. J. Biol. Chem. 66: 375-400.

Gorman, K., Hewitt, F., Denhoim, I. and Devine, G. (2001). New developments in insecticide resistance in the 
greenhouse whitefly (Trrialeurodes vaporariorum) and the two spotted spider mite (Tetranychus urticae). UK Pest Management Science. 58: 123-130.

Hiscox, J.D. and Israelstam, G.F. (1979). A method for extraction of chlorophyll from leaf tissue without maceration. Can. J. Bot. 57: 1332-1334.

Jackson, M.L. (1973). Vanamolybdate phosphoric yellow colour method for determination of phosphorus. Soil Chemical Analysis. Prentice Hall of India Pvt. Ltd. New Delhi.

James, D.G. and Price, T.S. (2002). Fecundity in two-spotted spider mite (Acari: Tetranychidae) increased by direct and systemic exposure to imidacloprid. J. Econ. Entomol. 95(4): 729-732.

Kennedy, G.G. and Smitley, D.R. (1985). Dispersal. In: Spider mites, their biology, natural enemies and control. (Helle W. and Sabelis M.W. eds). Vol. 1A, pp 233-242, Elsevier Amsterdam, The Netherlands.

Lindner, R.C. (1944). Rapid analytical methods for some inorganic constituents in plant tissue. Pl. Physiol. 19: 76 -86 .

Park, Y.L. and Lee, J.H. (2002). Leaf cell and tissue damage of cucumber caused by twospotted spider mite (Acari: Tetranychidae). J. Econ. Entomol. 95: 952-957.

Richards, L.A. (1954). Diagnosis and improvement of saline and alkaline soils. USDA Handbook No. 60.

Salman, M.S. (2007). Comparative toxicological studies of certain acaricides on two-spotted spider mite Tetranychus urticae Koch and its predator Stethorus gilvifrons Mulsant. Ph.D. Thesis, Plant Protection Department, Faculty of Agriculture, Suez Canal University.

Schoonhoven, L.M., Jermy, T. and Loon van, J.J.A. (1998). Plants as insect food: not the ideal. in: Insect-Plant Biology. pp 83-120, Chapman and Hall, London, United Kingdom.

Sivritepe, N., Kumral, N.A., Erturk, U., Yerlikaya, C. and Kumral, A. (2009). Responses of grapevines to two-spotted spider mite mediated biotic stress. J. Biol. Sci. 9(4): 311-318.

Tomczyk, A. and Kropczynska, D. (1985). Effects on the host plant, In: Spider Mites Their Biology, Natural Enemies And Control. (Helle W. and Sabelis M.W. (eds.), pp 317-329, Elsevier, Amsterdam.

Van Leeuwen, T., Vontas, J., Tsagkarakou, A., Dermauwa, W. and Tirry, L. (2010). Acaricide resistance mechanisms in the two-spotted spider mite Tetranychus urticae and other important Acari: A review. Insect Biochem. Mol. Biol. 40: 563-572.

Walsh, D. (2001). Spider mites-Secondary pests of Washington State wine grapes. http:/www. grapesoiety.org/2000meeting proceedings/ mtecontrol. html. 